\title{
Art Education in Nigerian Secondary Schools: A Case Study of Osun State
}

\author{
Rachael Olufunke Omisola \\ International School, Obafemi Awolowo University, Ile-Ife, Nigeria
}

\begin{abstract}
Arts is a tool which enhances the ability of the student to communicate and solve problems and with enormous entrepreneurship opportunities. In spite of this, art education is given little or no recognition in secondary institutions where the foundation for motivation to study the subject is expected to be laid. The study seeks to appraise the current state of things in selected schools. A qualitative study was conducted to determine perspectives of teachers, parents and students on the importance and relevance of art. School budgetary allocation for arts and science were assessed and art studios physically inspected.

Results. Investment in art education was found to be very low, and only two of fifty secondary schools in Ile-Ife, have an art studio. Time allocation for arts classes was also found to be poor and creativity and passion lost to restriction. Very few students take up arts as a study subject at senior secondary school level and parents have a poor perception of the subject. The current situation is that of low prioritization of arts education. Students are poorly motivated because most parents, students and school administrators have a poor perception of the prospects of the subject. It is necessary for stakeholders to explore ways of creating awareness and providing support for the teaching of this very rewarding subject.
\end{abstract}

\section{Introduction}

Art education refers to teaching, learning, instruction and programing based on the visual and tangible arts (Law and legal definition of Arts). It includes visual (fine arts and applied/industrial art) and non-visual (performing arts and literary arts) arts and requires individuals to be imaginative and creative. Enamhe [3] identified that for Nigeria, Arts improved social participation in ways that allows for respect for diversity, promotes inclusivity and therefore can promote political and economic stability. It therefore should be given premium in the school curriculum.

Currently, Nigeria has a failing economy and also security challenges, which increases its risk of being classified as a fragile state by the World Banks [4] [13]. A potential root cause of these is the educational system that is less able to train students to be creative and innovative as a means of addressing the growing poverty; but also, the growing tendency to be less respectful diversity. A possible contributing factor is the diminishing importance placed on arts education in Nigeria. The aim of this study is to review the state of arts education in secondary schools in Osun State of Nigeria, and highlight the potential arts education has to addressing current macro-level instability in Nigeria.

\section{Methods}

A qualitative study was conducted to determine perspectives of teachers, parents and students on the importance and relevance of art. Also, the school administration's budgetary allocation for arts and science were also assessed. In-depth interviews were conducted for students, parents and teachers in federal government, state government and private owned secondary schools.

In these schools, three students that took the final examination in fine arts and two students that offered fine arts but did not do the final examination were interviewed. A focus group discussion was conducted in the school with the students. The discussions explored their views and perspectives of fine arts as a study for the future and what can be done to improve arts education in secondary school to make it relevant to their future.

Parents were also interviewed. Two parents whose wards offered fine arts as a subject in the final examination, two whose wards studied fine art as a subject in senior secondary but did not take the examination, and three parents whose wards did not offered fine arts as a subject in the senior secondary school. The interviews explored their views and perspectives of fine arts as a study for the future and what can be done to improve arts education in secondary school to make it relevant to their future.

Teachers were also interviewed. Five fine arts teachers and five non-arts teachers were interviewed about their views and perspectives of fine arts as a study for the future and what can be done to improve 
arts education in secondary school to make it relevant to their future. The interviews were transcribed and a visual assessment of the arts studios in the three types of schools were conducted and pictures taken. All interviews and were audio-recorded, transcribed and analyzed using both thematic/content analysis. Codes were developed using a mix of both inductive and deductive coding methods. Inductive coding was implemented by developing codes from reading the data directly without the influence of other outside sources, while deductive coding was executed by developing codes from the study interview guides.

In addition, one Federal government owned school, one state government owned school and two privately owned schools were visited. The arts studios were assessed for availability of immoveable and moveable objects using a checklist developed by the author.

\section{Results}

The themes which emerged from the discussions include perception on the values and relevance of fine art education; factors responsible for the low or no turnover in the number of students registering for fine art; and challenges faced by students and schools to implement fine arts education. They also gave recommendations on how these challenges can be addressed.

\subsection{Perception on values and relevance of arts education by students}

The perception of some respondents believe the Arts Education is able to address the economic needs of individuals. Interviewed students identified why they chose to take up Arts classes. This includes parental and teachers' support.

“...I am doing visual art to have the knowledge of it. I love art, I love nature. So in case I want to further my knowledge on art later in the future, I will be able to say I offered it in secondary school, I will also continue with it"

...R3, IFAT_FGD_private school

".... I love my teacher; I love the way he teaches...my teacher gives me inspiration for offering the subject"

....R1, IFAT_FGD_private school

“.... I'm thinking of offering it in the university and to make money in my undergraduate.... I have passion for it"

. R, IFAT_FGD_privateschool

"... then I have parental support"

... R2, IFAT_FGD_private school
The respondents shared reasons why they opted out of continuing with Arts education in their senior years. A respondent believe that Arts is a skill that is easy to acquire at any time he wants too. Some were not interested in the subject while others are intimidated by the negative perspective of their peers towards Arts education. Some excerpts of the discussions are shown below:

“..... I'm going for engineering course and if I do engineering, it can be easy for me to go back to fine art, because fine art is something I can build by myself and engineering is not something that $I$ can just... engineering is not just something I can just go and do. Fine art is something I can start up myself. That is the reason.”

... R3, IFAT_FGD_private school

“... I wasn't really feeling the vibes.... the vibration it's very high, because of this, my friends are intimidating me."

....R4,IFAT_FGD_private school

“.... I felt like having it with the list of my subjects in WAEC and NECO exams but it was much load and as ......to shed the load....more than enough subjects...

\section{....R2,IFAT_FGD_private school}

“.... I joined in SS2. The teacher said instead of wasting his time that he wants to focus on people that want to write the subject in WAEC."

....R1, IFAT_FGD_private school

Discussants identified multiple values and relevance of Arts education beyond it being a source of income. These include self-development amongst others. Quotes include:

"....it gives you more patients; it brings out the beauty in everything; it works on ....it makes him more reserved and gentle."

...R2, IFAT_FGD_private school

“.... it's not only fun, it makes me feel ok too, it's just part of me"

...R2, IFAT_FGD_private School

“.... visual art can offer a lot, both physically and psychologically, visual art builds you. It make you see what others cannot see, it brings out the beauty in everything",

\section{...R3,IFAT_FGD_private school}

\subsection{Perception on values and relevance of arts education by parents}

A number of parents believes in the value of arts education because of it being a good source of 
income. A few reported their wards make income even as students from the skills they acquire from arts education. Others identified the aesthetic values associated with arts work.

“...Yes, I do. I do appreciate fine art. Sometime when I see my boy drawing at home, I will just be marvel at what his doing, so I like the knowledge of art.

....IFAT_IDI_Parent_tsc

“...some artistic designs I value it, because you can see it in every aspect of life you can see it, be it in the church setting, at home, in the school, in all phases."

....IFAT_IDI_Parent2_tsc

“... I love the subject because it gives values, it adds value, you see most of the structures, all these artistic design, I really appreciate it a lot and because of the positive roles played by the artist in our society"

.... IFAT_IDI_Parent2_tsc

".... any time he comes to the conferences center he will ask them to gather all the art works and he will buy them, and send them abroad, do you understand... he will be paid in dollars by the time they are sold over there."

....IFAT_IDI_Parent_tsc

Parents identified that Arts education in secondary schools face multiple challenges that reduces the number of students that take up the subject for study. These factors include low political will, low parental support, and inadequate investment in Arts education by school administrators. Also, respondents believe fine art is time consuming. An extract highlighting low political will:

"...if there is cooperation between parents, teachers, school heads and government, if there is cooperation... between the school, the parents, government and the school administrators, for example during a particular Governor's regime, he spoke up for those offering history. Now this current administration has scrapped history as a subject in schools."

\section{....IFAT_IDI_Parent_tsc}

\subsection{Perception on values and relevance of arts education by teachers}

Respondent opined that students' interest in quick gains have reduced their interest in choosing Arts education subjects because it requires time, concentration and endurance. Some excerpts of the discussions are shown below:

"Children of now a days don't have the grace of sitting somewhere doing something over and over again. they like doing think 'pim' and leave and art does not permit that one; will have to sit. ... another reason is the cost of materials many of which cannot is not affordable for many of the students."

.... IFAT_IDI_Teacher_tsc

"It's the same everywhere. They are very few students who register for WAEC exam. They are usually not more than two or three."

...IFAT_IDI_Teacher2_tsc

“...as a teacher, maybe you introduce them to so much practical work that will interest them, that can help them make income like beads and craftwork."

... IFAT_IDI_Teacher2_tsc

\subsection{Challenges Arts Education Face}

The challenges faced by Art Education include the negative attitude of school administrators towards art education, as they prioritize science education. This is a reflection of the low interest of the federal government and parents in arts education. Teachers also face challenges in rolling out art education classes which includes not having the needed teaching aids. Some excerpts of the discussions are shown below:

"I think the school is not really taking arts to be a serious subject. They are doing more of maybe maths, science, English, all those kind of things"

... IFAT_IDI_Student_tsc

"If there is no parent to support them it limits interest. For example, when we were asked to go and buy some for arts materials that day, it was the last penny on me. The materials they use are also scare because people don't know about them, and this increase the cost making it expensive for parents to procure."

....IFAT_IDI_Parent_tsc

"As teachers of art, we are having restriction in some assignments we give to students especially those that require they make huge investments in materials. "

....IFAT_IDI_Teacher_tsc

\subsection{Support for Arts Education}

Respondents opined that if parents adequately support Arts education, this can improve students' engagement with the subjects in secondary school. Schools also have to support arts education and equip arts studios to help make a difference. Some excerpts of the discussions are shown below:

"...once she showed interested, we went to buy the materials, and she was happy we went to buy those materials.

....IFAT_IDI_Parent_tsc 
“....mummy is very supportive. When daddy comes home, he asks me about my work, 'how is drawing?' My mum is just supportive in terms of 'tell me, what materials do you need?' 'What do you want to do?'."

....IFAT_IDI_Student_tsc

"I think we are not really serious in the school about Arts education. That time we were the ones buying things for ourselves doing everything...yes, apart from the carpenter, maybe plywood...."

.... IFAT_IDI_Student_tsc

"A studio with different materials personally helped me to be interested in the study. Most materials to us were usually free. They taught us well."

.... IFAT_FGD_Private School_Students_tsc

"Here parents are charged fees for arts education and they are paying per term. The school provides whatever the student needs. They come to studio, they use school drawing book they use school cardboard, they use school brushes, they use school colour, they use school pencil, the use eraser, they use school everything!"

... IFAT_IDI_Teacher_tsc

\section{Recommendations for improving Arts Education}

The recommendations on how to improve Arts education include development of school policies that promotes arts education throughout students' school years. Such policies should support both school and parents investment in pupils Arts education. Schools should also collaborate ex-students who are artists to run programs that can ginger students' interest in Arts education.

'....help them develop their passion and you should never make mistake of putting art as an inferior class. ..... in my life, that is why it affected me when I got to the senior secondary school. I couldn't draw, so I don't want them to stop drawing.

....IFAT_FGD_OAU Intl Schl_Students_tsc

“....provision of materials, provision of another art studio, they should increase your time, the timeline, that is the present time line is very short, and students will come, like now when they come to the art studio they start to see big foot...."

.... R2, IFAT_FGD_School 2 Student_tsc

“.... It's the work of the parents not government. When the parents are in one accord the children will not fail."

....IFAT_IDI_Parent_tsc

"You see those past artists, collaborate with them for direction. Pa Jimi Sholanke, collaborate with him, and so on, they should share their understanding with you.

....IFAT_IDI_Parent_tsc

"Provide all the needed facilities for the students, making the environment conducive. If possible, employ more art teachers. I will encourage other parents that they should not discourage students who love to take arts as a school subject, I will advise the parents to encourage them."

.... IFAT_IDI_Parent2_tsc

“....my first advice is that we should get a standard art studio ready: equip it with materials. If you have forty students in a class, the studio is supposed to be big enough for all those students to make a big circle. I am not saying that the school should increase the school fees to accommodate money to buy items for this school, as this will not work. We should allow our students to be involved in artistic activities, in exhibitions, in going for art workshops, art competition."

....IFAT_IDI_Teacher_tsc

Keys:

R- Respondent

I-Interviewer

IDI- In-depth interview

IFAT: Importance of Fine-Art Teaching

TSC: Transcripts

FGD: Focus Group Discussion

WAEC: West African Examination Council

NECO: National Examination Council

The Table 1 highlights the findings on school investment in Arts Education in Osun State. The invest is significantly lower than that of science education, with parents augmenting some of these financial investments required for arts education. Also, overall, the funding of arts education is best in private owned schools though teacher availability is best in the federal government owned schools. Students enrolment for fine arts as a subject in the final school examination is low irrespective of the type of school though lowest in state owned schools.

Table 2 shows the materials that were found in the art studios of the schools visited. Pictures of the Art studios are shown on Figures 1 (a) - (b), 2 and 3 (a) (g) while the artwork carried out by students of the various schools are shown on slides 4-11. 
Table 1. Investment in Arts Education by type of secondary schools in Osun State

\begin{tabular}{|l|c|c|c|}
\hline Variables & $\begin{array}{c}\text { Federal } \\
\text { Government } \\
\text { Owned }\end{array}$ & $\begin{array}{c}\text { State Government } \\
\text { owned }\end{array}$ & Private Owned \\
\hline $\begin{array}{l}\text { Proportion of students enrolled } \\
\text { for final examination }\end{array}$ & $97: 3$ & $99: 1$ & $98: 2$ \\
\hline $\begin{array}{l}\text { Financial investment } \\
\text { School parents }\end{array}$ & $98: 2$ & $10: 90$ & $50: 50$ \\
\hline Adequacy of teachers & $100 \%$ & $30-50 \%$ & $50 \%$ \\
\hline Imprest budget for fine arts & $0 \%$ & $1 \%$ & $30 \%$ \\
\hline $\begin{array}{l}\text { School procurement of } \\
\text { materials for fine arts }\end{array}$ & $0 \%$ & $1 \%$ & $25 \%$ \\
\hline $\begin{array}{l}\text { School budgetary allocation } \\
\text { for science: Arts education }\end{array}$ & $98: 2$ & $99: 1$ & $80: 20$ \\
\hline
\end{tabular}

Table 2. Availability of Immoveable and moveable objects in art studios in the different types of secondary schools in Osun State

\begin{tabular}{|c|c|c|c|}
\hline Variables & $\begin{array}{c}\text { Federal } \\
\text { Government } \\
\text { Owned }\end{array}$ & $\begin{array}{c}\text { State Government } \\
\text { Owned }\end{array}$ & Private Owned \\
\hline \multicolumn{4}{|c|}{ Immoveable } \\
\hline Fine arts studio & $\mathrm{Xxxx}$ & - & $\mathrm{Xxxx}$ \\
\hline Easel & $\mathrm{X}$ & - & - \\
\hline Donkey chairs & $\mathrm{Xxxx}$ & - & $\mathrm{Xxxx}$ \\
\hline Drawing boards & $\mathrm{X}$ & - & $\mathrm{Xxxx}$ \\
\hline Exhibition stands & $\mathrm{Xxxx}$ & - & $\mathrm{Xxxx}$ \\
\hline Exhibition boards & $\mathrm{Xxxx}$ & - & $\mathrm{Xxxx}$ \\
\hline Work benches & $\mathrm{Xxxx}$ & - & $\mathrm{Xxxx}$ \\
\hline Photo cutters & - & - & $\mathrm{Xxxx}$ \\
\hline \multicolumn{4}{|c|}{ Moveable } \\
\hline Colours & Students to provide & Students to provide & Students to provide \\
\hline Brushes & Students to provide & Students to provide & Students to provide \\
\hline Sharpeners & Students to provide & Students to provide & Students to provide \\
\hline Rulers & Students to provide & Students to provide & Students to provide \\
\hline Drawing sheets & Students to provide & Students to provide & Students to provide \\
\hline Pencils & Students to provide & Students to provide & Students to provide \\
\hline Pens & Students to provide & Students to provide & Students to provide \\
\hline Recommended Textbooks & Students to provide & Students to provide & Students to provide \\
\hline Chalk & Students to provide & Students to provide & Students to provide \\
\hline Fixatives & Students to provide & Students to provide & Students to provide \\
\hline Pastel & Students to provide & Students to provide & Students to provide \\
\hline Drawing pin & Students to provide & Students to provide & Students to provide \\
\hline Sketch pads & Students to provide & Students to provide & Students to provide \\
\hline
\end{tabular}

\section{Keys}

- Not Available

$\mathrm{x}$ Available, but not sufficient

xxxx-Available in sufficient number 


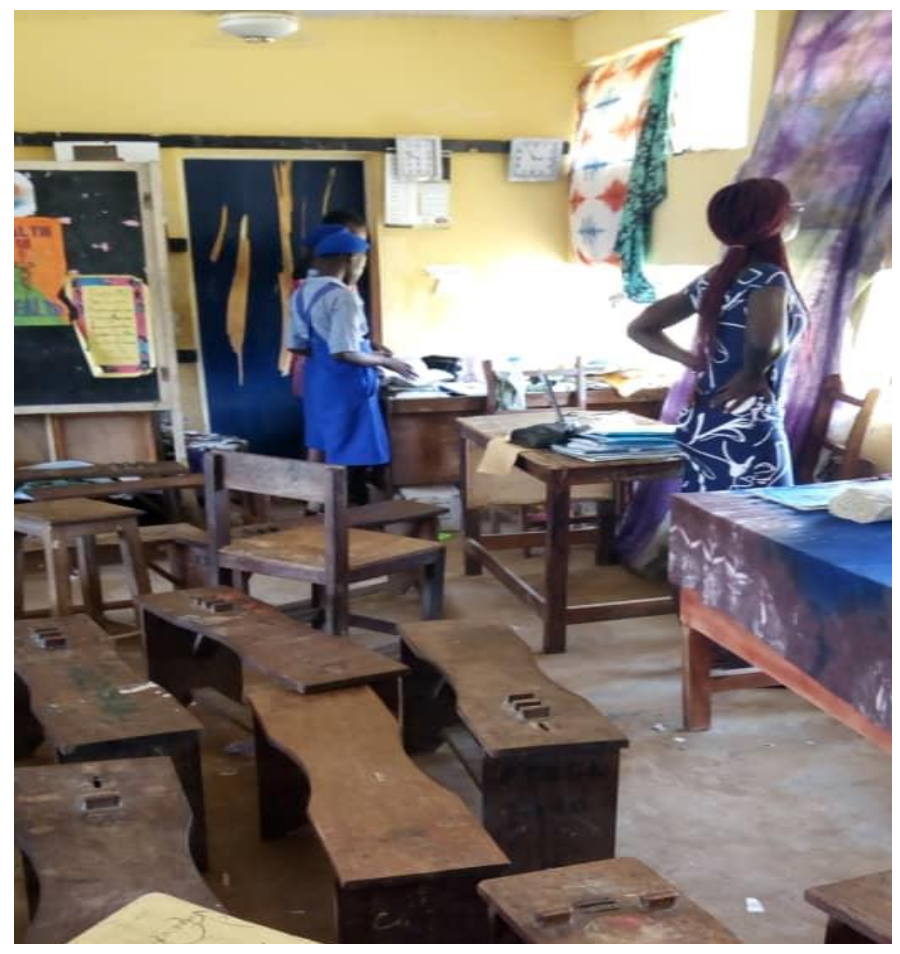

Figure 1 (a)

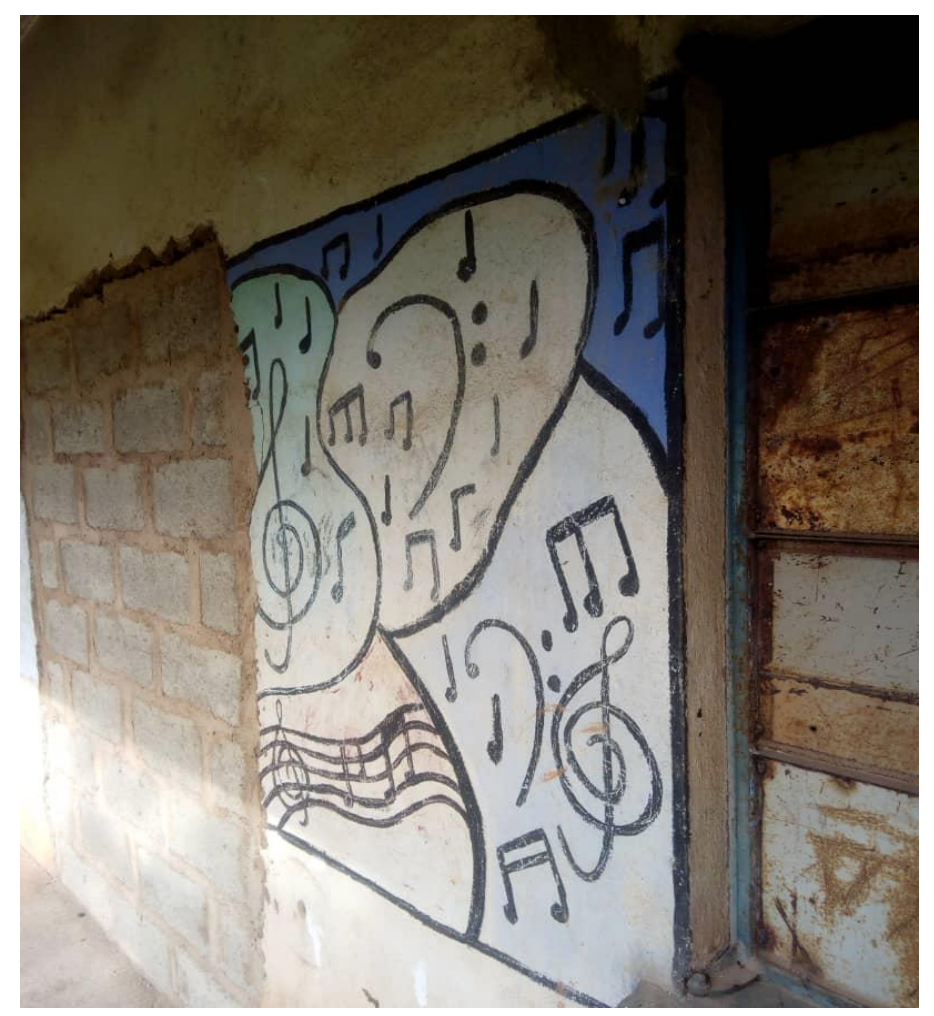

Figure 1 (b)

Figure 1 (a) - (b). Federal Govt School owned Art Studio 


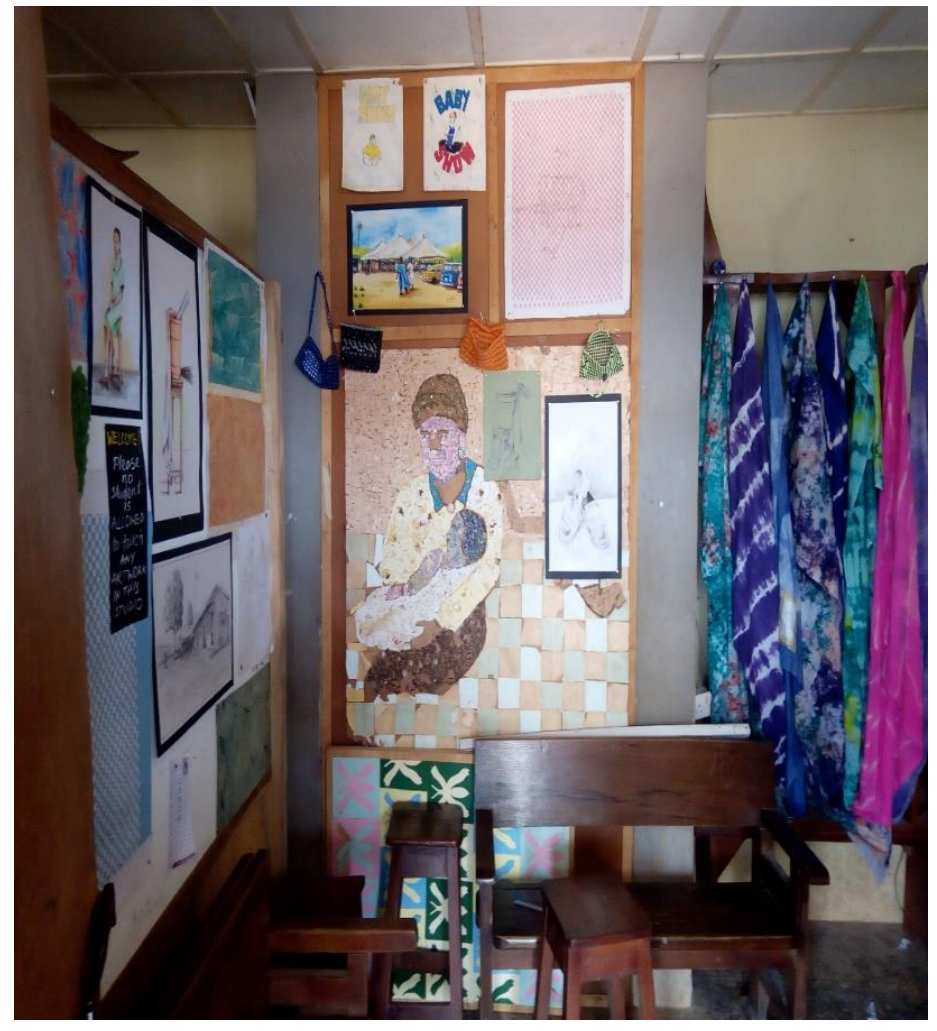

Figure 2. State-owned School Fine Art Studio (Abandoned)

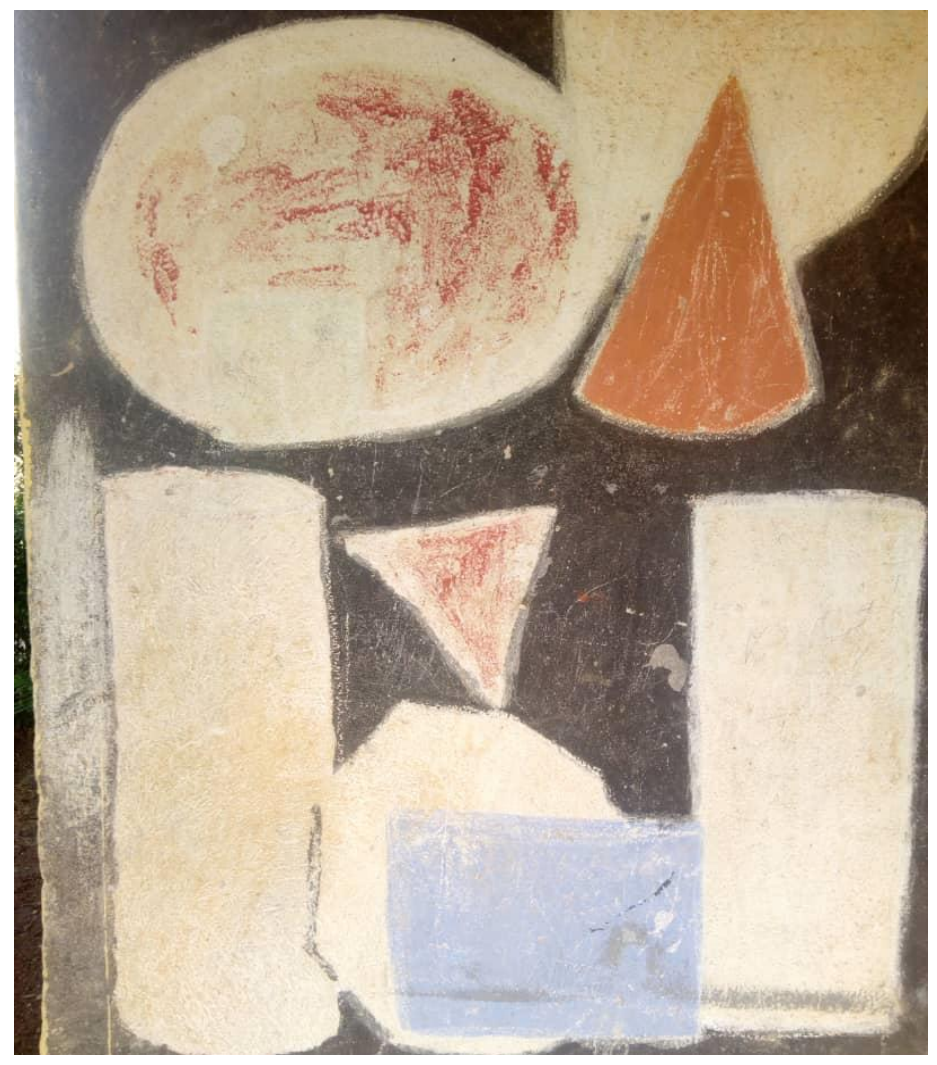

Figure 3 (a) 


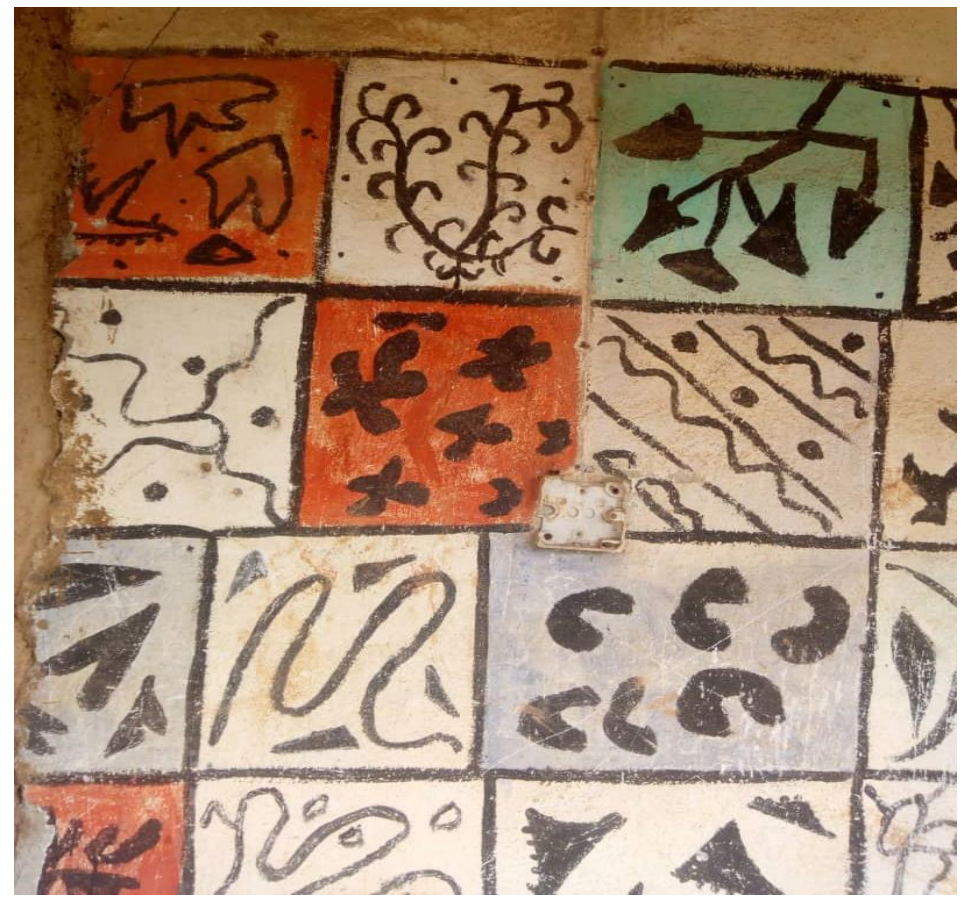

Figure 3 (b)

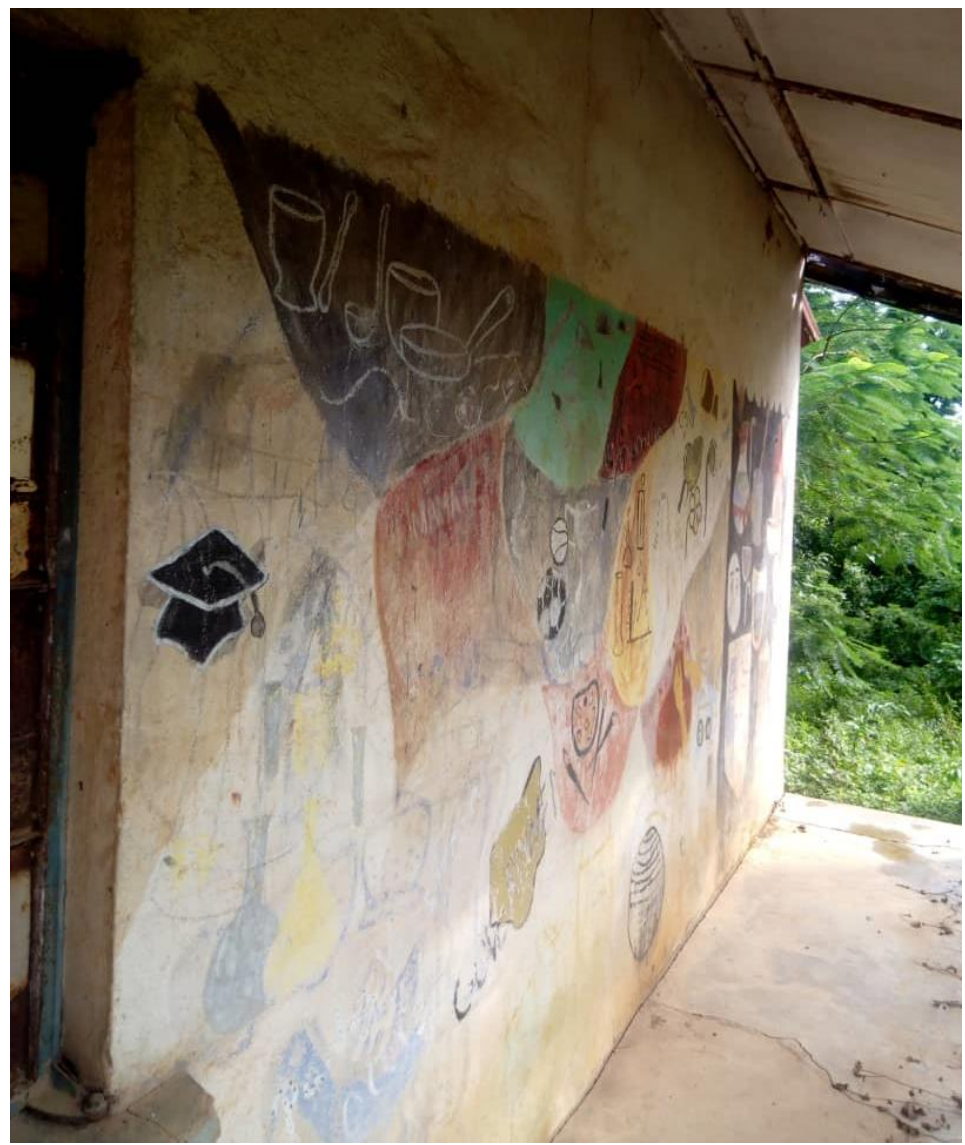

Figure 3 (c) 


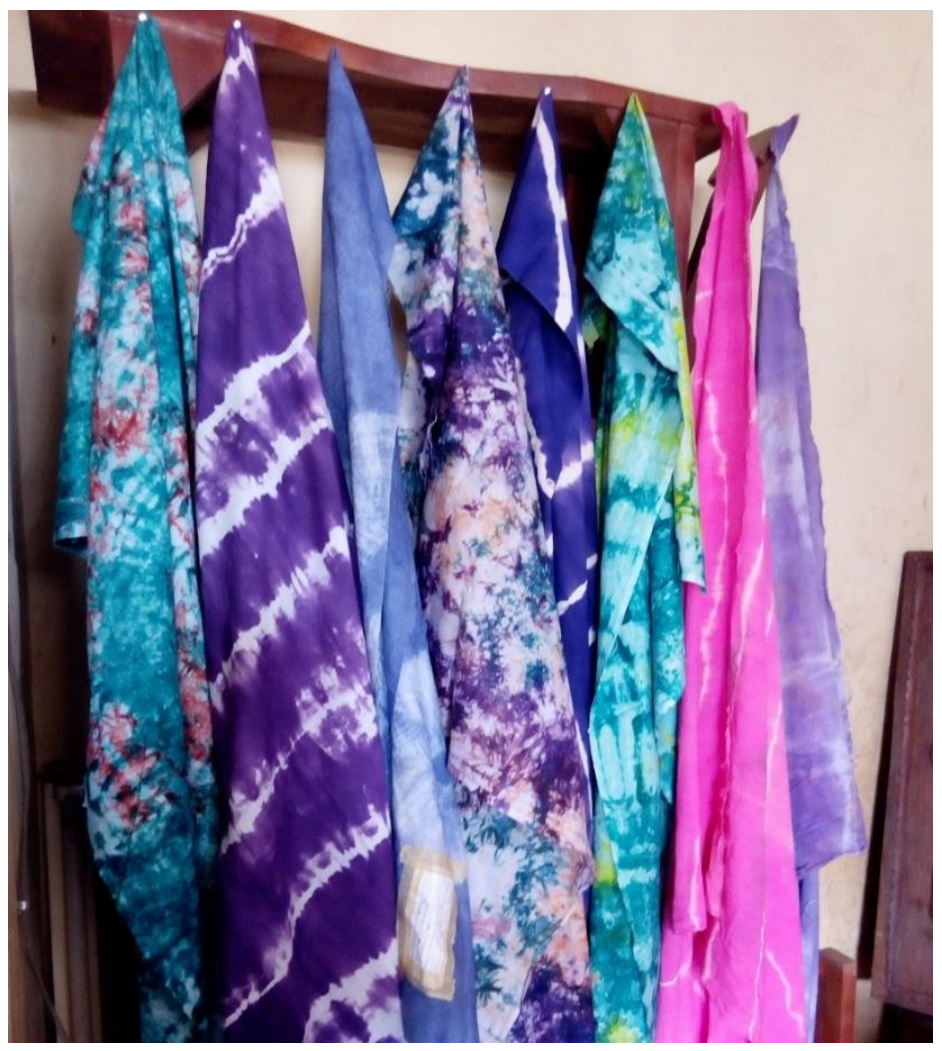

Figure 3 (d)

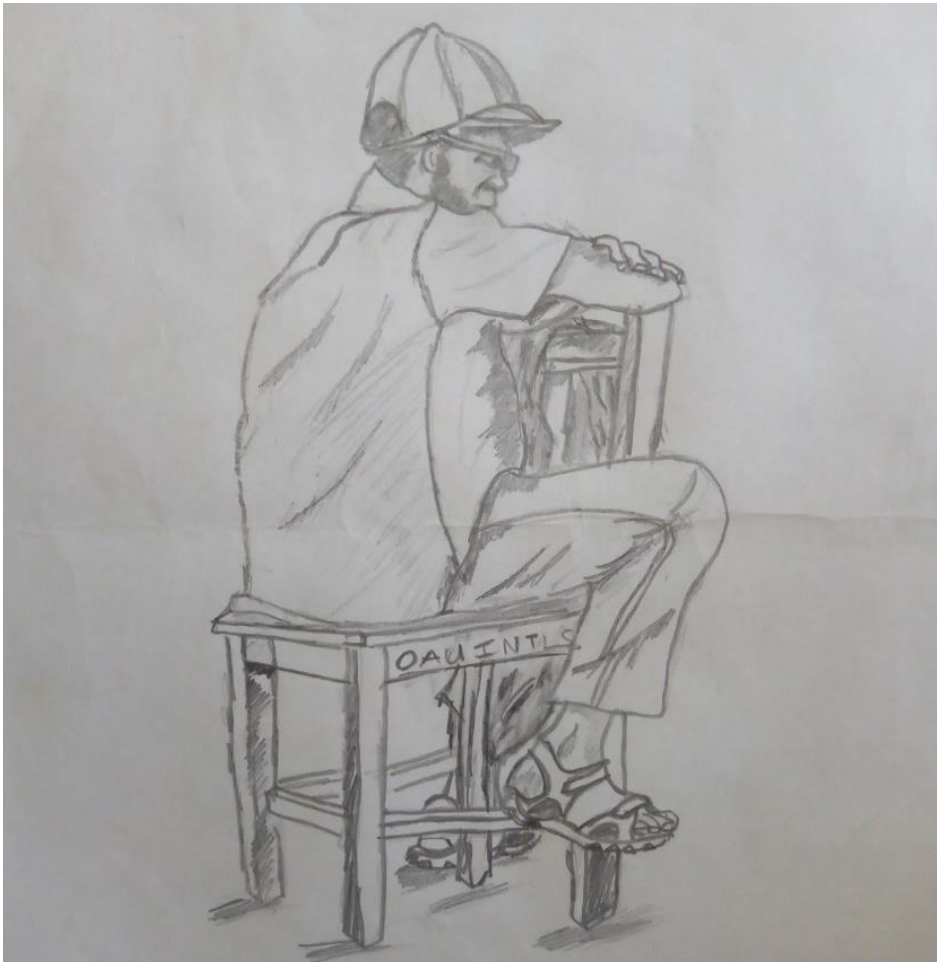

Figure $3(\mathrm{e})$ 


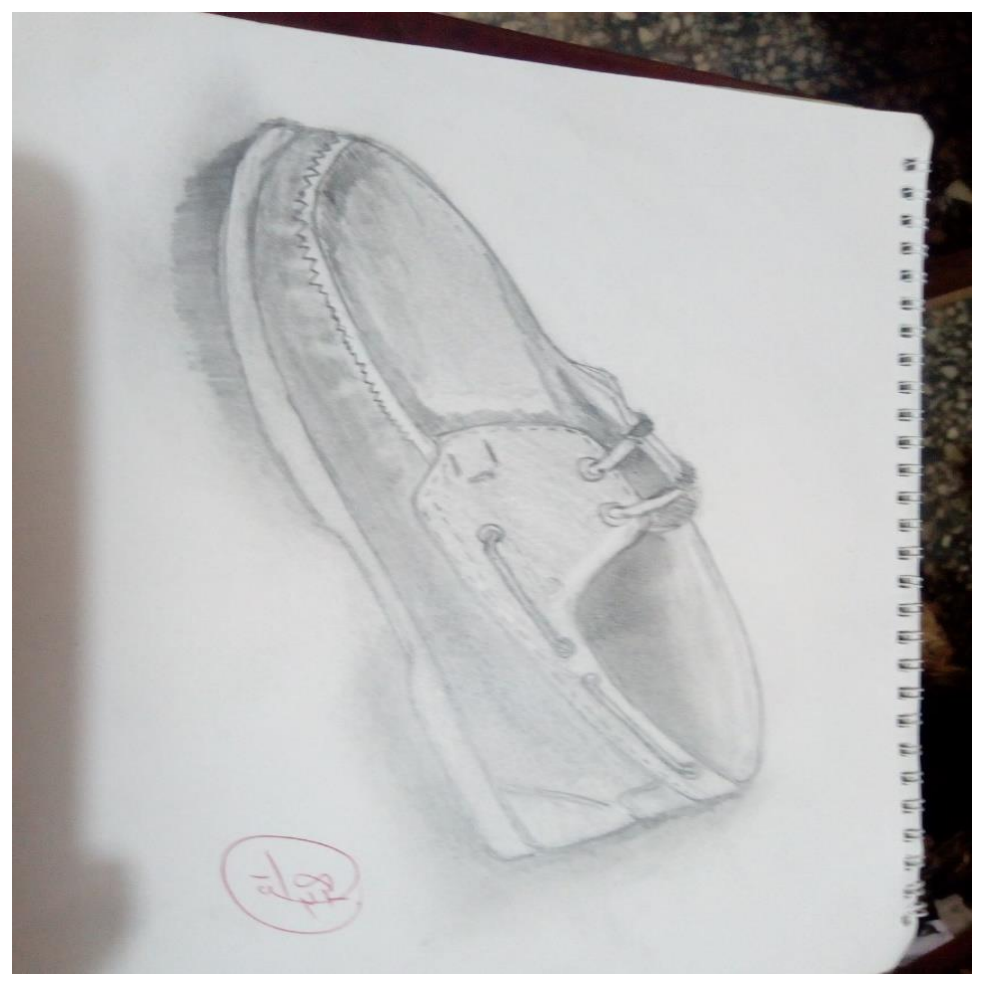

Figure 3 (f)

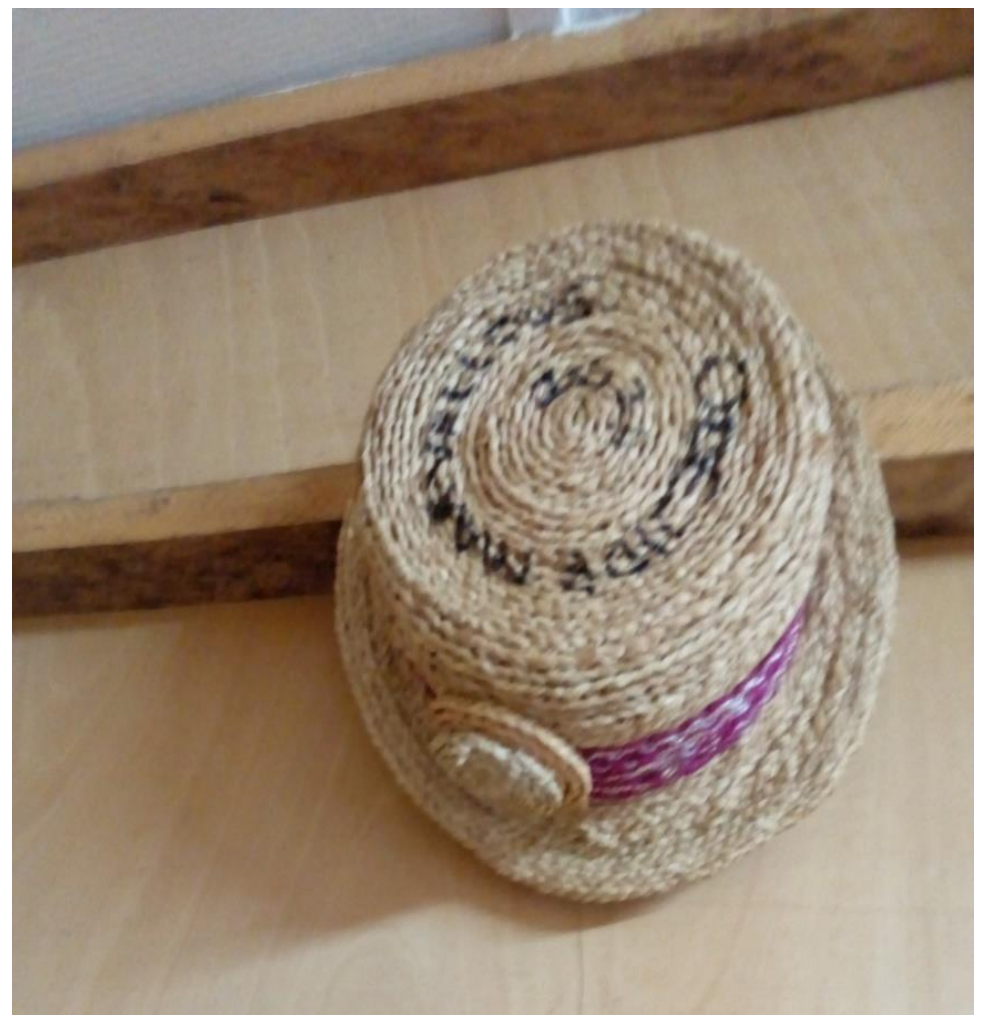

Figure 3 (g)

Figure 3 (a) - (g). Privately-owned School art Studio 


\section{Conclusion}

Findings from this study shows that art education is not being given sufficient recognition in most schools in Osun state and that students are poorly motivated to develop interest in the subject. This is most likely because most parents, students and school administrators have a poor perception of the prospects of art education and fail to appreciate its self-reliance potentials. The study identifies the need for stakeholders to initiate and explore different ways of creating awareness of the significance of arts education and providing support for teachers and interested students in order to build a generation with an artistic oriented mind. This could be in form of including participatory activities of both teachers and students in the curriculum and exploring the possibility of making art education a compulsory subject. Improvisation of local materials to solve artistic problems and ease financial challenges should also be looked into. Workshops, conferences and seminars should be organized to create awareness and opportunities for students to hear and learn more about art. Nigerian professional organizations/ bodies should rise up to the challenge of their common goal; to see to the welfare of art teaching and learning. Improvement of art museums, galleries, National theaters and African culture as a whole should be considered a top priority.

It should be noted that the study and practice of arts has the potential to address the growing problem of unemployment in Nigeria as it is an avenue for the development of entrepreneurship. Art education also improves creative thinking

\section{References}

[1] Banjoko Ibrahim "Visual Arts made Easy textbook for Schools and Colleges" Mavic Publishing Company Limited, Lagos.

[2] Egunlaae S "Essential Groundwork on Art" Omolayo Printing Press, Ado-Ekiti.

[3] Enamhe (2013). https://journal.lib.uoguelph.ca/index.p hp/ajote/article/view/1963/2934_(Access Date: 23 May 2020)

[4] Fasan (2018). https://blogs.lse.ac.uk/africaatlse /2018/ 06/13/nigeria-is-a-fragile-state-international-studies-proveit/ (Access Date: 23 May 2020).

[5] Gardner's (1980). "Art through the Ages", Harcourt Brace Jovanovich, inc., $7^{\text {th }}$ Edition.

[6] Giwa kehinde and Oladele Odanye "Basic Concepts of Cultural and Creative Arts for Junior Secondary Schools Book 1 -3" Holed Publishers, Ibadan.

[7] Ireye Paul "Concise Fine Arts for Secondary Schools" National Library of Nigeria cataloguing in Publication Data.
[8] National Council for Arts and Culture "Evolution in Nigeria Art - Series 2 (Journal)" The Ife Art School 1974 1984.

[9] Law and Legal Definition of Art Education. https://definitions.uslegal.com/a/art-education/ (Access Date: 23 May 2020).

[10] Ogumor Emu "Certificate Art for Junior and Senior Secondary Schools" University Press PLC.

[12] Penguin "Dictionary of Art and Artists, $4^{\text {th }}$ edition;"

[13] Premium Times (2019). https://allafrica.com/stories/2 01906250013.html (Access Date: 23 May 2020).

[14] Uzoagba I.N and Olarukoeba, Art History for Schools and Colleges Book Two.

[15] Willet Frank (1975). "African Art" Themes and Hudson, London.

[16] William Fagg and Margaret Plass (1988). "African Sculpture" Alfred A. brief incorporation, New York. 